\title{
Kernos
}

Revue internationale et pluridisciplinaire de religion grecque antique

32 | 2019

Varia

\section{Homer and the Poetics of Hades}

\section{Karolina Sekita}

\section{OpenEdition \\ Journals}

\section{Electronic version}

URL: https://journals.openedition.org/kernos/3183

DOI: $10.4000 /$ kernos.3183

ISSN: 2034-7871

\section{Publisher}

Centre international d'étude de la religion grecque antique

\section{Printed version}

Date of publication: 1 December 2019

Number of pages: $342-344$

ISBN: 978-2-87562-229-7

ISSN: 0776-3824

\section{Electronic reference}

Karolina Sekita, "Homer and the Poetics of Hades", Kernos [Online], 32 | 2019, Online since 01 October 2019, connection on 01 February 2022. URL: http://journals.openedition.org/kernos/3183 ; DOI: https://doi.org/10.4000/kernos.3183

This text was automatically generated on 1 February 2022.

Kernos 


\title{
Homer and the Poetics of Hades
}

\author{
Karolina Sekita
}

\section{REFERENCES}

George Alexander GAzIs, Homer and the Poetics of Hades, Oxford, Oxford University Press, 2018. 1 vol. $14,2 \times 22,2 \mathrm{~cm}, \mathrm{xi}+253$ p. ISBN : 978-0-19-878726-6.

1 This monograph explores Hades as a poetic resource. That is, as a space for an alternative presentation of the epic tradition, seen through diverse perspectives generated by a polyphonic narrative which allows human emotions to enter the cold realm of heroic kleos. It is an extremely rich and gripping study with a profound grasp of scholarship, and offering many important insights into narrative techniques and possible interpretations, which those interested in these topics, as well as the representation of the Homeric Underworld and its function in the narrative, cannot cast into oblivion.

2 The book is divided in two parts, preceded by an introduction and followed by conclusions, bibliography, a general index and an index of passages cited. The introduction consists of two parts. The first is a lengthy survey of Homeric enargeia ("vividness"); this is initially slightly confusing, as its relevance for the discussion to follow is not immediately stated; only at the end of p. 12 does the reader learn what is at stake, which is elaborated in the following part of the introduction. In this second part of the introduction we are given an initial presentation of the concept of 'Hades as a poetic resource' through exploration of the characteristics of the realm of the dead (its invisibility and overwhelming darkness, in opposition to the light which the living enjoy). The properties of invisibility and darkness ascribed to the Underworld by Homer, according to the author, are responsible for "the absence of important markers of Muse narrative", focused on heroic kleos, in the passages of the Homeric epic dealing with the Underworld, and enables "a self-consciously alternative approach to the epic past" (p. 15), a thesis which forms the main strand of discussion in the book. 
Of the two main parts which constitute the core of the book, the first regards Hades in the Iliad from the perspective of the fates of heroes, their kleos, and the representation of the Underworld. This is accomplished and very readable but, nevertheless, one is left with the impression that in the main it does not significantly add to the discussion already present in scholarship. An exception is the acute observation that Hades, through the association (signalled by George A. Gazis [G.A.G] in his interpretation of the opening lines of the Iliad ) with the accomplishment of Zeus' will, is made in a way "the guardian of fate", which may be interpreted as "the guardian of tradition during the heroic age and its storehouse after it has come to an end" (p. 34). Important, but passed

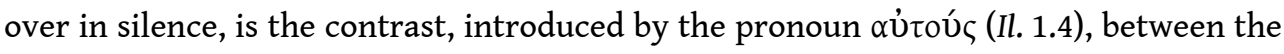
heroes themselves (that is identified as and through their corporeal reality; thus, the translation "their bodies" instead of "themselves" is misleading for the concept expressed in these lines), left as prey for dogs and birds, and their psychai (identifying heroes' lives as sealed in the moment of death), which are hurled down to Hades. This contrast would readily support G.A.G.'s recurrent emphasis (starting with the following section: a detailed interpretation of the dream of Achilles) on eidola as images of the heroes "with a deeply personalised focus on their past" (p. 76). The analysis of the dream of Achilles in the first part of the main text, as well as further discussion in the chapters of the second, notably larger, part, dealing with "Nekyia" in book 11 of the Odyssey, are preceded by individual surveys of the current state of scholarship, which allows G.A.G. neatly to set the scene for his arguments in a very reader-friendly manner. Textual problems and scholiastic interpretations are addressed in detail as well as a range of scholarly interpretations of individual points.

4 The second part starts with an introduction to the "poetics of Hades" in the Odyssey. This is followed by a thorough analysis of the "Nekyia", the "catalogue of the heroines", the "intermezzo", and the "catalogue of heroes". Here there is a special focus on the text from the linguistic and narratological perspectives, with Odysseus as internal focalizer. The insights produced by G.A.G.'s analysis are for the most part persuasive, and prove G.A.G. to be a very sensitive reader, capable of subtle interpretations. Nevertheless, there are some apparent omissions (such as the problem of interpretation of the "Nekyia" as an "actual" descent of the hero to the Underworld), some problematic areas taken for granted (such as the "[common] katabatic tradition"), and others dismissed too easily (e.g. the image of the Underworld in book 24). The reason for the omission of the representation of the Underworld in book 24 is at least explained in the introduction (p. 21): the passage raises textual problems which could not be addressed without adding considerably to the length of the text; and the description adds nothing "substantially" new to the discussion of book 11. And yet the main difference between these two narrative representations lies in new elements of the Underworld scenery that appear in book 24, and the fact that it is narrated by the poet, and not by Odysseus, who on G.A.G.'s interpretation had a privileged access to the other world in book 11, one not allowed to the Muses or the poet (p. 83, 104, 209). In the light of similar tone of the poet's narration of book 24, G.A.G.'s position becomes difficult to sustain. The character of the confessions or stories of the shades cannot be denied to be anti-heroic (i.e., not channelled into kleos) and "deliberately subjective" (p. 83), which results in alternative versions of epic tradition. Yet, given the broader spectrum of Hades "as repository of personal experiences" (p. 104), it is still interesting why Odysseus, after having conversed with many shades (though only in some cases does he explicitly say that he was told the 
tale), decides to narrate stories only of some of them, and denies a voice to the others if, as G.A.G. claims, "only in Hades, where personal experience defies even the most powerful of taboos, [one] can be given a hearing" (p. 174). G.A.G. follows, however, Doherty's suggestion (p. 159, 161) that "the catalogue of heroines" is the "gift" to Arete, the Phaeacian queen, to please her (the catalogue otherwise has little to do with Odysseus' own story). If so, is the hero really telling the truth, as G.A.G. insists (p. 163164 ; even though he notes the division in scholarship on this matter), or is he choosing particular "truths" from among other truths ultimately to help himself? One could believe that the latter solution is more likely (especially on the narrative level) rather than allowing primarily "new voices to be heard and old stories to be told differently" (p. 156). G.A.G. seems to be accepting the possibility of Odysseus' manipulating the story later, while the hero talks to Achilles (p. 187), and when he is ignored by Ajax (p. 198) ; in conclusion, G.A.G. states that "the choice of the hero [Ajax] not to relate his story presents Odysseus with the opportunity of (mis)framing his own story as Underworld narrative", and this is because "to assert himself, Odysseus needs to assert absolute control even over the narrative resources of Hades" (p. 203). G.A.G.'s primary interpretation, however, is focused on the perspective of Hades and its context. And he has rightly concluded in the case of the "catalogue of heroes" that "it provides us with a unique opportunity of observing how epic tradition reflects upon itself when its protagonists are long gone and relegated to Hades. In this respect the second part of the 'Nekyia' epitomizes Homer's poetics of Hades by having the heroes themselves confront their own personal experience, thus presenting us with a subjective perspective of the past that pulls away from the traditional epic ideals of kleos and time $\bar{e}$ (p. 167).

5 A very interesting and powerful observation is that the narration of the individual shades bears affinities "with the voice and outlook of Greek lyric poets such as Stesichorus but also looks ahead to the subjective, emotionally intense, and selfconsciously alternative poetics of Greek tragedy" (p. 213). G.A.G. upholds this firmly over several pages ( 83 [where additionally Sappho is mentioned], 155, 207, 211), but, regrettably, he makes only one short parallel between Iphimedeia's narration in the catalogue and Stesichorus' Geryoneis (p. 153). Further analysis of this observation would have been welcome as well as exploration of any consequences for our understanding of the "poetics of Hades" in book 11, be it the direct influence of Homer on lyric poets or the reconsideration of the dating of the composition of the lines in question.

6 Leaving aside specific interpretative disagreements, the book provides a very thorough analysis of the Underworld setting, function, and the perspective and context of Achilles' dream in the Iliad and of book 11 of the Odyssey. It shows the importance of Hades and its "poetic" within both texts, realized on various levels of narration, featuring the shift from the Underworld as Odysseus' resource to the Underworld as a resource of very human stories, their potential in general as well as at times their prophetic aspects. The stories mirror the shades in the Underworld - they represent what is left of life, which is not much but, as G.A.G. proves, it is enough to allow the poet to retell the "familiar" from an "unfamiliar" perspective. 


\section{AUTHORS}

KAROLINA SEKITA

University of Oxford 